\title{
Molecular typing, phenotypic and genotypic assessment of antibiotic resistance and virulence factors amongst the Staphylococcus aureus bacteria isolated from raw chicken meat
}

\author{
Nazanin Fazel \\ Islamic Azad University Shahrekord Branch \\ Sepideh Karimi \\ Islamic Azad University Shahrekord Branch \\ Hassan Momtaz ( $\square$ hamomtaz@yahoo.com ) \\ Islamic Azad University https://orcid.org/0000-0002-2282-9552
}

\section{Research article}

Keywords: Staphylococcus aureus, Virulence factors, Antibiotic resistance properties, ERIC-PCR, Chicken meat

Posted Date: April 12th, 2020

DOl: https://doi.org/10.21203/rs.3.rs-21570/v1

License: (1) This work is licensed under a Creative Commons Attribution 4.0 International License. Read Full License 


\section{Abstract}

Background: Staphylococcus aureus is an important cause of foodborne diseases due to the consumption of contaminated raw chicken meat. The present research was performed to evaluate the phenotypic and genotypic properties of antibiotic resistance, virulence factor profiles and molecular typing of $S$. aureus strains isolated from chicken meat. A total of $36 \mathrm{~S}$. aureus strains were isolated from raw chicken meat samples. Phenotypic pattern of antibiotic resistance was assessed by disk diffusion. Distribution of antibiotic resistance and virulence genes was evaluated by PCR. Molecular typing of isolates was perform ed by the ERIC-PCR.

Results: Considering the over than $80 \%$ similarity, 36 S. aureus isolates were classified in 9 different profiles with 43 to $100 \%$ similarities. S. aureus strains showed the highest incidence of resistance against penicillin (100\%), tetracycline $(91.66 \%)$, cephalothin $(77.77 \%)$, ciprofloxacin (75\%), erythromycin (75\%), mupirocin (63.88\%), clindamycin (61.11\%) and trimethoprim/sulfamethoxazole (61.11\%). The most commonly detected antibiotic resistance genes amid the $S$. aureus isolates were mecA $(100 \%)$, tetK (80.55\%), tetM (66.66\%), aacA-D (61.11\%), msrA (55.55\%) and ermA (55.55\%). Total distribution of etB, etA, tsst-1, clfA and coa virulence factors amongst the $S$. aureus strains was $61.11 \%$, $58.33 \%, 13.88 \%, 75 \%$ and $100 \%$, respectively.

Conclusions: Genetic cluster of bacteria affected the antibiotic resistance and virulence characters of $S$. aureus strains. $S$. aureus strains with the same ERIC-genetic cluster had similar antibiotic resistance and virulence characters which may show their similar origins. Presence of one or more virulence factors and antibiotic resistance genes amongst the resistant-S. aureus strains signifies an important public health threat rendering the consumption of raw or undercooked chicken meat.

\section{Background}

Chicken meat harbors variety of imperative dietary supplements including proteins, carbohydrate, fats, minerals and vitamins with healthy advantageous for human [1-4]. Thus, their regular daily consumption has been widely recommended. In keeping with this, human involvement in the production, inspection and processing of chicken meat increased the risk of microbial contamination and occurrence of foodborne diseases [1-4].

Staphylococcus aureus (S. aureus) is a Gram-positive, catalase positive, and cocci-shaped bacterium characteristically originate from nose and respiratory tract and on the skin [5-8]. S. aureus is responsible for plain nosocomial and community-acquired infections, foodborne diseases and food poisoning [5-8]. Occurrence of diverse kinds of gastrointestinal diseases known by abdominal cramps, nausea, vomiting, weakness and diarrhea and also toxic shock syndrome (TSS) are accredited to $S$. aureus [5-8].

Foodborne diseases caused by $S$. aureus bacteria are mostly resist toward antibiotic therapy. Currently, resistant-S. aureus has become a thoughtful issue in health-care centers and the community $[6,9]$. Epidemiological surveys have recognized that the $S$. aureus bacteria isolated from diverse kinds of foodstuffs, particularly those with animal origins, harbored considerable incidence of resistance toward frequently used antibiotic agents, especially aminoglycosides, penicillins, tetracyclines, fluoroquinolones, cephalosporins, and macrolides [6, 9]. Presence of the genes encode resistance toward methicillin (mecA), aminoglycosides (aacA-D), streptogramins (vatA, vatB and vatC), tetracyclines (tetK and tetM), lincosamides ( $\operatorname{lin} A$ ) and macrolides (ermA, ermB, ermC, $m s r A$ and $m s r B$ ), is one of the main modes for occurrence of antibiotic resistance amongst the $S$. aureus bacteria $[6,9,10]$.

Some potential virulence factors are accompanied in the pathogenesis of clinical infections and in some cases foodborne diseases caused by $S$. aureus $[8,11]$. Toxic shock syndrome toxin-1 (tsst-1), coagulase encoding gene (coa), exfoliative toxins A and B (eta and etb) and clumping factor $(c / f A)$ are frequently detected in $S$. aureus strains isolated from human clinical infections and foodstuffs $[8,11,12]$.

Genotypic-based molecular analysis of bacterial strains has an imperative role in their classifications especially in outbreaks of nosocomial infections and foodborne diseases. Enterobacterial Repetitive Intergenic Consensus Polymerase Chain Reaction (ERIC-PCR) is a technique with high ability to generate DNA fingerprints that differentiate between bacterial strains [13]. Application of diverse kinds of ERIC-PCR methods has been used for molecular typing of $S$. aureus isolates [13].

Notwithstanding the great number of reports and researches on the dynamics of $S$. aureus, supplementary investigations is desirable, particularly in some area like Iran where there is a comparative scarcity of data on the epidemiology of $S$. aureus's foodborne diseases. Thus, an existing survey was performed to assess the phenotypic and genotypic properties of antibiotic resistance, distribution of virulence factors and molecular typing of $S$. aureus bacteria isolated from raw chicken meat samples in Iran.

\section{Results}

\section{Molecular typing of S. aureus strains}


The present survey was conducted to assess the phenotypic and genotypic properties, virulence factor profiles and molecular typing of a total of $36 \mathrm{~S}$. aureus strains isolated from chicken meat.

Figure 1 reveals the ERIC-based molecular typing of $S$. aureus strains isolated from chicken meat samples. Considering the over than $80 \%$ similarity, 36 S. aureus isolates were classified in 9 different profiles with 43 to $100 \%$ similarities. Isolates No 2, 11, 20, 24, $35,5,12,13$ and 36 were classified in diverse profiles. The lowest similarity (43\%) was found for isolates No 20, 11, 2 and 24. An achieved major clonal cluster was ERIC-cluster No 3 with 7 S. aureus isolates. Diverse ERIC-types were further analyzed for phenotypic and genotypic properties of antibiotic resistance and distribution of virulence factors.

\section{Phenotypic profile of antibiotic resistance}

Table 2 reveals the phenotypic pattern of antibiotic resistance of diverse ERIC-types of $S$. aureus strains. $S$. aureus strains harbored the uppermost incidence of resistance toward penicillin (100\%), tetracycline (91.66\%), cephalothin (77.77\%), ciprofloxacin (75\%), erythromycin (75\%), mupirocin (63.88\%), clindamycin (61.11\%) and trimethoprim/sulfamethoxazole (61.11\%). Isolated bacteria exhibited the lowest incidence of resistance toward nitrofurantoin (16.66\%) and rifampin (41.66\%) antibiotic agents. Statistically significant difference was found between ERIC-type of $S$. aureus isolates and incidence of antibiotic resistance $(P<0.05)$. 
Table 2

Phenotypic pattern of antibiotic resistance of diverse ERIC-types of the $S$. aureus strains isolated from chicken meat.

\begin{tabular}{|c|c|c|c|c|c|c|c|c|c|c|c|c|}
\hline \multirow{2}{*}{$\begin{array}{l}\text { ERIC } \\
\text { Type }\end{array}$} & \multirow{2}{*}{$\begin{array}{l}\text { Isolates } \\
\text { No }\end{array}$} & \multicolumn{11}{|c|}{ Phenotypic profile of antibiotic resistance (\%) } \\
\hline & & F300* & SXT25 & TE30 & RA5 & Mup & E15 & AZM15 & Cln & CIP5 & CL30 & P10 \\
\hline \multirow[t]{7}{*}{ Type 1} & 21 & - & + & + & + & + & + & + & + & + & + & + \\
\hline & 30 & - & - & + & + & + & + & + & + & + & - & + \\
\hline & 27 & + & + & + & - & - & + & + & + & + & + & + \\
\hline & 31 & - & - & - & + & + & + & + & - & + & + & + \\
\hline & 25 & - & + & + & + & - & - & - & - & - & + & + \\
\hline & 26 & - & - & + & - & + & + & + & - & + & + & + \\
\hline & 34 & - & + & - & - & - & + & + & + & + & + & + \\
\hline \multirow[t]{4}{*}{ Type 2} & 9 & - & + & + & + & + & + & + & + & + & + & + \\
\hline & 16 & - & + & + & + & + & + & + & + & + & + & + \\
\hline & 15 & - & + & + & + & + & - & - & + & - & + & + \\
\hline & 18 & + & - & - & - & + & - & + & - & - & + & + \\
\hline \multirow[t]{4}{*}{ Type 3} & 3 & - & + & + & - & + & + & - & - & + & - & + \\
\hline & 8 & - & + & + & - & - & + & + & - & + & + & + \\
\hline & 14 & - & + & + & + & - & + & - & - & + & + & + \\
\hline & 35 & - & + & + & + & + & + & + & - & + & + & + \\
\hline \multirow[t]{4}{*}{ Type 4} & 28 & - & + & + & - & - & + & - & + & + & + & + \\
\hline & 29 & - & + & + & + & + & + & + & + & + & + & + \\
\hline & 12 & - & + & + & - & + & + & - & + & + & + & + \\
\hline & 5 & - & + & + & + & + & - & + & + & - & + & + \\
\hline \multirow[t]{4}{*}{ Type 5} & 4 & + & - & + & - & + & + & - & + & + & - & + \\
\hline & 10 & - & - & + & - & + & + & - & + & + & + & + \\
\hline & 17 & - & - & + & - & + & + & - & + & + & - & + \\
\hline & 13 & - & + & + & + & - & - & + & + & - & + & + \\
\hline \multirow[t]{3}{*}{ Type 6} & 6 & + & - & + & - & + & + & + & + & + & - & + \\
\hline & 19 & - & + & + & + & - & - & + & + & - & + & + \\
\hline & 36 & - & - & + & - & - & + & + & - & + & + & + \\
\hline \multirow[t]{2}{*}{ Type 7} & 1 & - & - & + & - & + & + & - & - & + & + & + \\
\hline & 7 & - & + & + & + & - & - & + & - & - & + & + \\
\hline \multirow[t]{2}{*}{ Type 8} & 32 & - & - & + & - & + & + & + & - & + & - & + \\
\hline & 33 & - & - & + & - & + & + & - & - & + & - & + \\
\hline \multirow[t]{2}{*}{ Type 9} & 22 & - & - & + & - & + & + & - & + & + & + & + \\
\hline & 23 & + & + & + & + & + & & + & + & - & + & + \\
\hline $\begin{array}{l}\text { Type } \\
10\end{array}$ & 20 & - & + & + & - & - & + & - & + & + & + & + \\
\hline
\end{tabular}

${ }^{*}$ F300 = Nitrofurantoin, SXT25 = Trimethoprim/sulfamethoxazole, TE30 $=$ Tetracycline, RA5 = Rifampin, Mup = Mupirocin, E15 = Erythromycin, AZM15 = Azithromycin, CIn = Clindamycin, CIP5 = Ciprofloxacin, CL30 = Cephalothin, P10 = Penicillin, 


\begin{tabular}{|c|c|c|c|c|c|c|c|c|c|c|c|c|}
\hline \multirow{2}{*}{$\begin{array}{l}\text { ERIC } \\
\text { Type }\end{array}$} & \multirow{2}{*}{$\begin{array}{l}\text { Isolates } \\
\text { No }\end{array}$} & \multicolumn{11}{|c|}{ Phenotypic profile of antibiotic resistance (\%) } \\
\hline & & $\mathrm{F} 300^{*}$ & SXT25 & TE30 & RA5 & Mup & E15 & AZM15 & Cln & CIP5 & CL30 & P10 \\
\hline $\begin{array}{l}\text { Type } \\
11\end{array}$ & 24 & - & + & + & - & + & + & - & + & + & + & + \\
\hline $\begin{array}{l}\text { Type } \\
12\end{array}$ & 11 & + & + & + & - & - & + & - & + & + & + & + \\
\hline $\begin{array}{l}\text { Type } \\
13\end{array}$ & 2 & - & - & + & - & - & & + & - & - & - & + \\
\hline Total (36) & & $\begin{array}{l}6 \\
(16.66)\end{array}$ & $\begin{array}{l}22 \\
(61.11)\end{array}$ & $\begin{array}{l}33 \\
(91.66)\end{array}$ & $\begin{array}{l}15 \\
(41.66)\end{array}$ & $\begin{array}{l}23 \\
(63.88)\end{array}$ & $\begin{array}{l}27 \\
(75)\end{array}$ & $\begin{array}{l}21 \\
(58.33)\end{array}$ & $\begin{array}{l}22 \\
(61.11)\end{array}$ & $\begin{array}{l}27 \\
(75)\end{array}$ & $\begin{array}{l}28 \\
(77.77)\end{array}$ & $\begin{array}{l}36 \\
(100)\end{array}$ \\
\hline
\end{tabular}

\section{Genotypic profile of antibiotic resistance}

Table 3 reveals the genotypic pattern of antibiotic resistance of diverse ERIC-types of the $S$. aureus strains isolated from chicken meat. MecA (100\%), tetK (80.55\%), tetM (66.66\%), aacA-D (61.11\%), $\operatorname{msr} A(55.55 \%)$ and ermA (55.55\%) were the most frequently detected antibiotic resistance genes amongst the $S$. aureus isolates. $\operatorname{VatC}(8.33 \%)$, vatB $(36.11 \%)$, ermC $(38.88 \%)$ and vatA $(41.66 \%)$ had the lowermost incidence amongst all examined antibiotic resistance genes. Statistically significant difference was found between ERIC-type of $S$. aureus isolates and incidence of antibiotic resistance genes $(P<0.05)$. Additionally, statistically significant differences was found amid the distribution of tetK and tetM $(P<0.05)$, ermA and ermC $(P<0.05)$, vatA and vatB and vatC $(P<0.05)$ and finally $m s r A$ and $m s r B(P<0.05)$. 
Table 3

Genotypic pattern of antibiotic resistance of diverse ERIC-types of the $S$. aureus strains isolated from chicken meat.

\begin{tabular}{|c|c|c|c|c|c|c|c|c|c|c|c|c|c|}
\hline \multirow{2}{*}{$\begin{array}{l}\text { ERIC } \\
\text { Type }\end{array}$} & \multirow{2}{*}{$\begin{array}{l}\text { Isolates } \\
\text { No }\end{array}$} & \multicolumn{12}{|c|}{ Profile of antibiotic resistance genes (\%) } \\
\hline & & $\operatorname{lin} A$ & ermc & ermA & vatc & vatB & vatA & tetM & tetK & aacA-D & $\mathrm{msrB}$ & msra & $\operatorname{mec} A$ \\
\hline \multirow{7}{*}{$\begin{array}{l}\text { Type } \\
1\end{array}$} & 21 & + & - & + & - & + & - & + & + & + & - & + & + \\
\hline & 30 & - & + & - & - & - & + & + & - & + & + & - & + \\
\hline & 27 & + & - & + & - & - & + & - & + & + & + & + & + \\
\hline & 31 & + & - & + & - & - & - & + & + & - & - & + & + \\
\hline & 25 & - & + & - & + & - & + & + & - & + & + & - & + \\
\hline & 26 & - & - & + & - & - & - & + & + & + & + & - & + \\
\hline & 34 & + & + & - & - & - & + & - & + & + & + & + & + \\
\hline \multirow{4}{*}{$\begin{array}{l}\text { Type } \\
2\end{array}$} & 9 & - & - & + & - & - & + & + & - & + & - & + & + \\
\hline & 16 & + & - & - & - & + & + & + & + & + & + & - & + \\
\hline & 15 & - & + & + & - & - & + & + & + & + & - & - & + \\
\hline & 18 & + & - & + & - & - & + & + & - & + & - & + & + \\
\hline \multirow{4}{*}{$\begin{array}{l}\text { Type } \\
3\end{array}$} & 3 & + & - & + & - & + & - & - & + & - & + & + & + \\
\hline & 8 & - & + & - & - & + & - & + & + & + & - & + & + \\
\hline & 14 & - & + & - & - & - & - & + & + & + & + & - & + \\
\hline & 35 & + & - & + & - & + & - & - & + & - & - & + & + \\
\hline \multirow{4}{*}{$\begin{array}{l}\text { Type } \\
4\end{array}$} & 28 & - & - & - & - & - & + & - & + & - & + & - & + \\
\hline & 29 & - & + & - & - & - & + & + & + & + & - & + & + \\
\hline & 12 & - & - & + & - & - & + & - & + & - & + & - & + \\
\hline & 5 & - & + & - & - & - & + & + & - & - & - & + & + \\
\hline \multirow{4}{*}{$\begin{array}{l}\text { Type } \\
5\end{array}$} & 4 & + & - & + & + & - & - & - & + & + & - & + & + \\
\hline & 10 & + & + & - & - & + & - & + & + & - & + & & + \\
\hline & 17 & + & + & - & - & - & + & + & + & - & + & - & + \\
\hline & 13 & + & - & + & + & - & - & - & + & + & - & + & + \\
\hline \multirow{3}{*}{$\begin{array}{l}\text { Type } \\
6\end{array}$} & 6 & - & - & & - & + & - & + & + & - & + & - & + \\
\hline & 19 & - & - & + & - & - & + & + & + & + & - & + & + \\
\hline & 36 & - & - & + & - & - & - & + & + & - & - & + & + \\
\hline \multirow{2}{*}{$\begin{array}{l}\text { Type } \\
7\end{array}$} & 1 & + & - & + & - & - & - & - & + & + & - & + & + \\
\hline & 7 & + & - & + & - & - & - & - & + & + & + & - & + \\
\hline \multirow{2}{*}{$\begin{array}{l}\text { Type } \\
8\end{array}$} & 32 & - & + & - & - & + & - & + & - & - & + & - & + \\
\hline & 33 & - & + & - & - & + & - & - & + & + & - & + & + \\
\hline \multirow{2}{*}{$\begin{array}{l}\text { Type } \\
9\end{array}$} & 22 & + & - & + & - & - & + & - & + & - & + & - & + \\
\hline & 23 & + & - & + & - & + & - & + & + & + & - & + & + \\
\hline $\begin{array}{l}\text { Type } \\
10\end{array}$ & 20 & - & + & - & - & + & - & + & - & + & + & + & + \\
\hline $\begin{array}{l}\text { Type } \\
11\end{array}$ & 24 & + & - & + & - & - & - & + & + & - & - & + & + \\
\hline
\end{tabular}




\begin{tabular}{|c|c|c|c|c|c|c|c|c|c|c|c|c|c|}
\hline \multirow{2}{*}{$\begin{array}{l}\text { ERIC } \\
\text { Type }\end{array}$} & \multirow{2}{*}{$\begin{array}{l}\text { Isolates } \\
\text { No }\end{array}$} & \multicolumn{12}{|c|}{ Profile of antibiotic resistance genes (\%) } \\
\hline & & $\operatorname{lin} A$ & ermc & ermA & vatc & vatB & vatA & tetM & tetK & aacA-D & msrB & msra & mecA \\
\hline $\begin{array}{l}\text { Type } \\
12\end{array}$ & 11 & - & + & - & - & + & - & + & + & + & + & - & + \\
\hline $\begin{array}{l}\text { Type } \\
13\end{array}$ & 2 & + & & + & - & + & - & + & + & - & + & - & + \\
\hline \multicolumn{2}{|c|}{ Total (36) } & $\begin{array}{l}18 \\
(50)\end{array}$ & $\begin{array}{l}14 \\
(38.88)\end{array}$ & $\begin{array}{l}20 \\
(55.55)\end{array}$ & $\begin{array}{l}3 \\
(8.33)\end{array}$ & $\begin{array}{l}13 \\
(36.11)\end{array}$ & $\begin{array}{l}15 \\
(41.66)\end{array}$ & $\begin{array}{l}24 \\
(66.66)\end{array}$ & $\begin{array}{l}29 \\
(80.55)\end{array}$ & $\begin{array}{l}22 \\
(61.11)\end{array}$ & $\begin{array}{l}19 \\
(52.77)\end{array}$ & $\begin{array}{l}20 \\
(55.55)\end{array}$ & $\begin{array}{l}36 \\
(100)\end{array}$ \\
\hline
\end{tabular}

\section{Profile of virulence factors}

Table 4 reveals the distribution of virulence factors of diverse ERIC-types of the $S$. aureus strains isolated from chicken meat. Total distribution of etB, etA, tsst-1, clfA and coa virulence factors amongst the $S$. aureus strains was $61.11 \%, 58.33 \%, 13.88 \%, 75 \%$ and $100 \%$, respectively. Statistically significant difference was found between ERIC-type of $S$. aureus isolates and incidence of virulence factors $(P<$ 0.05). 
Table 4

Distribution of virulence factors of diverse ERIC-types of the $S$. aureus strains isolated from chicken meat.

\begin{tabular}{|c|c|c|c|c|c|c|}
\hline \multirow[t]{2}{*}{ ERIC Type } & \multirow[t]{2}{*}{ Isolates No } & \multicolumn{5}{|c|}{ Profile of virulence factors (\%) } \\
\hline & & etB & etA & tsst-1 & clfA & coa \\
\hline \multirow[t]{7}{*}{ Type 1} & 21 & + & + & - & + & + \\
\hline & 30 & + & + & - & + & + \\
\hline & 27 & + & + & - & + & + \\
\hline & 31 & + & + & - & + & + \\
\hline & 25 & + & + & - & - & + \\
\hline & 26 & + & + & - & + & + \\
\hline & 34 & + & + & - & + & + \\
\hline \multirow[t]{4}{*}{ Type 2} & 9 & + & + & - & + & + \\
\hline & 16 & + & + & - & + & + \\
\hline & 15 & + & + & - & + & + \\
\hline & 18 & + & - & - & + & + \\
\hline \multirow[t]{4}{*}{ Type 3} & 3 & + & + & - & + & + \\
\hline & 8 & - & + & - & + & + \\
\hline & 14 & + & + & - & + & + \\
\hline & 35 & + & + & - & + & + \\
\hline \multirow[t]{4}{*}{ Type 4} & 28 & + & + & - & + & + \\
\hline & 29 & + & + & - & + & + \\
\hline & 12 & - & - & + & - & + \\
\hline & 5 & + & - & - & + & + \\
\hline \multirow[t]{4}{*}{ Type 5} & 4 & - & - & - & + & + \\
\hline & 10 & - & - & + & + & + \\
\hline & 17 & - & - & + & + & + \\
\hline & 13 & - & - & - & + & + \\
\hline \multirow[t]{3}{*}{ Type 6} & 6 & + & - & - & + & + \\
\hline & 19 & - & - & - & + & + \\
\hline & 36 & + & + & - & + & + \\
\hline \multirow[t]{2}{*}{ Type 7} & 1 & + & + & - & + & + \\
\hline & 7 & - & - & - & - & + \\
\hline \multirow[t]{2}{*}{ Type 8} & 32 & - & - & - & + & + \\
\hline & 33 & + & - & + & - & + \\
\hline \multirow[t]{2}{*}{ Type 9} & 22 & - & + & - & - & + \\
\hline & 23 & - & - & - & + & + \\
\hline Type 10 & 20 & + & + & - & - & + \\
\hline Type 11 & 24 & - & - & + & - & + \\
\hline
\end{tabular}




\begin{tabular}{|lllllll|}
\hline ERIC Type & Isolates No & \multicolumn{5}{l}{ Profile of virulence factors (\%) } \\
\cline { 3 - 7 } & & etB & etA & tsst-1 & clfA & coa \\
\hline Type 12 & 11 & - & + & - & - & + \\
\hline Type 13 & 2 & - & - & - & - & + \\
\hline Total (36) & & $22(61.11)$ & $21(58.33)$ & $5(13.88)$ & $27(75)$ & $36(100)$ \\
\hline
\end{tabular}

\section{Discussion}

From the epidemiological prospective, it is essential to know the exact ways of transmission of antibiotic resistant-bacteria to human population. Foods with animal origin have a critical role in transmission of antibiotic resistant-bacteria to human [14-17]. Chicken meat is considered as a ubiquitous source of antibiotic resistant-S. aureus $[18,19]$.

An existing survey was carried out to assess the phenotypic and genotypic properties of antibiotic resistance, characterization of virulence factors and molecular typing of a total of $36 \mathrm{~S}$. aureus bacteria isolated from raw chicken meat samples. Our findings described that the $S$. aureus bacteria exhibited the highest incidence of resistance toward penicillin, tetracycline, cephalothin, ciprofloxacin, erythromycin, mupirocin, clindamycin and trimethoprim/sulfamethoxazole which was assisted with attendance of mecA, tetK, tetM, aacA-D, msrA and ermA antibiotic resistance genes. Widespread and unauthorized administration of antimicrobials and disinfectant solutions in both medicine and veterinary have been considered to be a major factor in the emergence of antibiotic resistance amongst $S$. aureus bacteria. Similarly, considerable incidence of resistance of $S$. aureus bacteria recovered from chicken meat samples toward penicillin, tetracycline, cephalothin, ciprofloxacin, erythromycin, mupirocin, clindamycin and trimethoprim/sulfamethoxazole antibiotic agents was conveyed from China [19], Bangladesh [20], Nepal [21], Pakistan [22], United States [23] and Iran [24]. V Govender, E Madoroba, K Magwedere, G Fosgate and L Kuonza [25] stated that the $S$. aureus bacteria isolated from poultry meat in South Africa harbored resistance toward penicillin (27.80\%), ampicillin (22.20\%), oxacillin (15.30\%), cefoxitin (20.80\%), ceftiofur (5.60\%), oxytetracycline $(43.10 \%)$, clindamycin $(22.20 \%)$, gentamicin $(18.10 \%)$, erythromycin (13.90\%), sulfamethoxazole (6.90\%), enrofloxacin (1.40\%), ciprofloxacin $(0 \%)$, vancomycin $(0 \%)$ and florfenicol $(0 \%)$ antibiotic agents. DG Amoako, AM Somboro, AL Abia, C Molechan, K Perrett, LA Bester and SY Essack [26] reported that the $S$. aureus bacteria isolated from poultry products harbored the highest incidence of resistance toward tetracycline (61.67\%), penicillin G (55.83\%), erythromycin (54.17\%), clindamycin (43.33\%), rifampicin (40.83\%), doxycycline (36.67\%), ampicillin (34.17\%), amikacin (30.83\%), moxifloxacin (30.83\%), trimethoprim-sulfamethoxazole (30.00\%), levofloxacin (23.33\%), ciprofloxacin (15.83\%), gentamicin (8.33\%) and cefoxitin $(7.50 \%)$. Surveys conducted on America, Asia, Africa, and Europe continents revealed the high incidence of antibiotic resistant-S. aureus in foods with animal origins $[27,28]$. Similar pattern of resistance of $S$. aureus bacteria isolated from different kinds of foodstuff and clinical samples have been reported toward fluoroquinolones, aminoglycosides, macrolides [6, 8, 29-32], tetracyclines [6, 8, 29, 30], cephems [6, 8, 29-31], folate inhibitors [6, 8, 29-32], penicillins [6, 8, 29-31], phenicols [6, 8, 29, 30], lincosamides [6, 8, 29-31], and ansamycins [6, 8, 29, 30] antibiotic agents. Differences in the opinion of medical and veterinary practitioners in antibiotic prescription, observation of ethics and rules in the use of antibiotics, availability or lack of antibiotics and their prices are probable reasons of differences found in the incidence of resistance of $S$. aureus strains in numerous investigations. Genotypic pattern of antibiotic resistance of $S$. aureus strains isolated from chicken meat samples has less evaluated. Our findings revealed that $m e c A$, tetK, tetM, aacA-D, $m s r A$ and ermA were the main antibiotic resistance genes amongst the $S$. aureus isolates. Thus, phenotypic pattern of antibiotic resistance of $S$. aureus strains was confirmed by the genotypic pattern. However, our findings disclosed higher incidence of phenotypic profile of resistance than genotypic profile. For example, all of the tetracycline-resistant $S$. aureus bacteria didn't harbored tetK or tetM antibiotic resistance genes. This matter was also existed for other antibiotic agents and resistance genes. It is maybe owing to the fact that presence of antibiotic resistance genes is one of the known procedures for occurrence of antibiotic resistance in bacteria. Otherwise, several mechanisms have been identified to induce antibiotic resistance in bacteria including reduced permeability of bacteria to antibiotics, efflux antibiotic's active pumps to out of the bacterial cell, change in antibiotic target site, inactivation of antibiotics through hydrolysis or changes in their structure, occurrence of genetic mutations and access of bacteria to the secondary metabolic pathways that compensate the antibiotic-inhibited reactions. OE Akanbi, HA Njom, J Fri, AC Otigbu and AM Clarke [33] described that $m e c A$, ermB and tet $M$ were the most commonly detected antibiotic resistance genes amongst the $S$. aureus bacteria recovered from food samples which was relatively similar to our findings. Similar to our results, high incidence of mecA, tetK, tetM, vatA, ermA, and $m s r A$ was also described in the $S$. aureus bacteria recovered from chicken meat in Egypt [34], bovine mastitis milk and pig carcasses and clinical infections in Germany [35, 36], ruminants in Iran [37], and raw milk in Switzerland [38]. Another Iranian survey [39] represented the high distribution of aacA-aphD, mecA, tetK and tetM, ermB, ermA, ermT, ermC, msrB and $m s r A$ antibiotic resistance markers likewise to our survey. H Hizlisoy, NE Onmaz, F Karadal, A Serhat, Y Yildirim, Z Gonulalan and H Kilic [40] reported that the distribution of aacA-aphD, tetK, tetM, vatA, vatB, blaZ, ermA, ermC, mecA, vanA and vanB antibiotic resistance genes amongst the $S$. aureus strains isolated from foods with animal origin in Turkey was $100 \%, 44 \%, 37 \%, 0 \%, 100 \%, 91 \%, 53 \%, 47 \%, 100 \%, 0 \%$, and $11 \%$, respectively. A total of $61.11 \%$ of the $S$. aureus strains 
harbored the aacA-D gene which encode resistance toward gentamicin. Similar findings were also reported by (Australia), RM Gomes, MRQ Bomfim, MJ Trindade, LM Farias and SG Santos [42] (Brazil), G Adwan, K Adwan, N Jarrar and A Amleh [43] (Palestine), and L Oksuz, C Dupieux, A Tristan, M Bes, J Etienne and N Gurler [44] (Turkey). ErmA and ermC genes are mainly attributed to occurrence of resistance toward erythromycin. Total distribution of ermA and ermC genes amongst the S. aureus strains were $55.55 \%$ and $8.33 \%$, respectively. Likewise, $T$ Zmantar, K Chaieb, FB Abdallah, AB Kahla-Nakbi, AB Hassen, K Mahdouani and A Bakhrouf [45] conveyed that the incidence of ermA and erm $\mathrm{C}$ amongst the $S$. aureus strains isolated from Tunisia were $22.80 \%$ and $17.10 \%$, respectively. Similar to our findings, higher incidence of ermA than erm $C$ antibiotic resistance genes was also reported previously $[5,6,46,47]$. However, higher distribution of erm $C(74.50 \%)$ than ermA (30.90\%) gene was reported in a study conducted by G Adwan, $\mathrm{K}$ Adwan, $\mathrm{N}$ Jarrar and A Amleh [43]. MecA gene was detected in all examined $S$. aureus bacteria. The distribution of the mecA gene in the $S$. aureus bacteria isolated from foods with animal origins in India [16], Korea [48] and Turkey [49] were 77\%, 61.90\% and 57\%, respectively which all were lower than our report. The high detection rate of the mecA gene found in the present survey, might be due to its horizontal transmission amid the $S$. aureus strains obtained together in food processing environment. VatA, vatB and vatC antibiotic resistance genes were detected in $41.66 \%, 36.11 \%$ and $8.33 \%$ of $S$. aureus strains. These genes are mainly encoded resistance against quinupristin-dalfopristin and streptogramin antibiotic agents. R Ranjbar, MHS Shahreza, E Rahimi and $\mathrm{N}$ Jonaidi-Jafari [50]reported that the total incidence of vatA, vatB and vatC antibiotic resistance genes amongst the $\mathrm{S}$. aureus strains isolated from foods with animal origins were $38.55 \%, 19.27 \%$ and $9.63 \%$, respectively. Our findings addressed the higher distribution of tetK ( $80.55 \%$ ) than tetM (66.66\%) antibiotic resistance genes. Similarly, higher incidence of tetK than tetM antibiotic resistance genes was also reported previously $[5,6,8,10,40,46,50,51]$. Higher incidence of antibiotic resistance genes reported in some previously published papers is due to the fact that they examined the distribution of antibiotic resistance genes amongst the methicillin-resistant $S$. aureus (MRSA) strains.

Toxins are usually regarded as one of the major factors in the virulence of $S$. aureus globally, and hence, it is significant to evaluate their distribution amongst isolates from food with respect to measuring public health risks. Results of an existing survey revealed that the distribution of $c o a, c / f A$, et $B$, et $A$ and $t s s t-1$ virulence factors amongst the $S$. aureus isolates were $100 \%, 75 \%, 61.11 \%, 58.33 \%$ and $13.88 \%$, respectively. Presence of virulence $S$. aureus amongst the chicken meat samples exhibited an imperative public health threat regarding the consumption of raw or undercooked chicken meat samples. In the same way, these genes were predominant in the S. aureus strains isolated from foods with animal origins [52-54]. The genes encoding exfoliative toxin isoforms (etA and et $B$ ) were the most important factors associated with the pathogenesis of the $S$. aureus infections. Exfoliative toxins play a role in host colonization and the invasion of injured mucosa and skin. Thus, the high distributions of et $A$ and et $B$ genes in examined chicken meat samples could be due to the transmission of $S$. aureus strains from the skin of workers and staffs of slaughterhouses [55]. H Li, P Andersen, M Stegger, R Sieber, H ngmer, N Staubrand, A Dalsgaard and J Leisner [56] reported that the $S$. aureus strains isolated from poultry meat samples didn't harbor et $A$ and et $B$ virulence factors, while the distribution of the tsst-1 gene was $3.40 \%$. The tsst- 1 gene is a super-antigen that can cause a diversity of clinical complications. X Yang, S Yu, Q Wu, J Zhang, S Wu and D Rong [57] reported that the distribution of tsst-1, et $A$ and etB virulence factors amongst the $S$. aureus strains isolated from foods with animal origins were $7.24 \%, 10.14 \%$ and $10.14 \%$, respectively. It has been reported that $S$. aureus clones containing eta, etb, and tsst are increasingly responsible for severe infections. CB Waryah, J Gogoi-Tiwari, K Wells, KY Eto, $\mathrm{E}$ Masoumi, P Costantino, M Kotiw and T Mukkur [58] reported that the incidence of clfA gene amongst the $S$. aureus strains isolated from human origins on Australia was $83.87 \%$. Additionally, coa and clfA virulence genes were detected in $63.41 \%$ and $76.82 \%$ of S. aureus strains isolated from chicken meat in previous Iranian survey [8]. Clumping factor is a significant adhesion protein of $S$. aureus that is governed by clfA gene. This virulence factor is critical for colonization and establishment of infections caused by the $S$. aureus. It contributes in the pathogenesis of diseases caused by $S$. aureus by facilitating bacterial binding via soluble or immobilized fibrinogen as fibrinogen plays an important role in platelet thrombus formation [59]. Coagulase protein has the capability to convert fibrinogen to fibrin and has enough potentials to be a virulence factor in infections caused by the $S$. aureus. It is codified by the coa gene that holds a preserved and a recurrent polymorphic region that can be used to evaluate relatedness amid $S$. aureus isolates [60]. High distribution of clfA and coa virulence factors amongst the $S$. aureus strains isolated from foods with animal origins was reported from Brazil [53], Thailand [61], Switzerland [62] and India [63].

Our survey also showed that the $S$. aureus strains of the same molecular cluster (ERIC-type) had the same profiles of antibiotic resistance and virulence factors. This matter maybe show the common source of contamination of chicken meat samples with $S$. aureus with the same molecular cluster.

\section{Conclusions}

In conclusion, presence of $S$. aureus in examined samples which was accompanied with the high incidence of resistance toward diverse classes of antibiotic agents and also dissimilar antibiotic resistance genes and virulence factors was reported in the current survey. High incidence of resistance of $S$. aureus bacteria toward penicillin, tetracycline, cephalothin, ciprofloxacin, erythromycin, mupirocin, clindamycin and trimethoprim/sulfamethoxazole which was assisted with attendance of $\operatorname{mec} A$, tetK, tetM, aacA-D, $m s r A$ and ermA antibiotic resistance genes may pose an imperative menace regarding the role of raw or undercooked chicken meat consumption on transmission of antibiotic-

Page $10 / 18$ 
resistant $S$. aureus. Incidence of resistance toward human-based antibiotics can indirectly show the origin of $S$. aureus isolates. It seems that penicillin, tetracycline, cephalothin, ciprofloxacin, erythromycin, mupirocin, clindamycin and trimethoprim/sulfamethoxazole are not effective therapeutic agents in the cases of $S$. aureus foodborne diseases in Iran. Simultaneous presence of one or more antibiotic resistance genes and virulence factors in the antibiotic-resistant $S$. aureus bacteria specify an imperative public health threat about the consumption of raw or undercooked chicken meat samples. Thirty-six $S$. aureus strains were classified into the 9 diverse genetic clusters according to the ERIC-PCR. S. aureus strains with similar genetic cluster had similar phenotypic and genotypic properties of antibiotic resistance and distribution of virulence markers. Thus, they may have the same origin. Poultry slaughterhouses can be severely contaminated with foodborne pathogens, the maintenance of slaughter hygiene, regular microbiological monitoring of carcasses, implementation of good manufacturing practices and a food safety system such as the HACCP system are essential to minimize the risk to the consumer. Additionally, appropriate cooking of raw chicken meat before consumption, prevention from cross-contamination and antibiotic prescription based on the outcomes of disk diffusion can diminish the risk of transmission of resistant-S. aureus bacteria from chicken meat to human population. Our research highlights the importance of control the antibiotic susceptibility of $S$. aureus in the foodstuffs such as food producing animals, retail foods, and even human beings, and these information could be used proactively to assist Iranian industries to progress better-quality food safety measures. Otherwise, on the basis of these observations, we recommend that attention should be paid by governments and individuals to prevent the further spread of antibiotic-resistant $S$. aureus. However, supplementary surveys are essential to determine more epidemiological features of the $S$. aureus bacteria in raw chicken meat.

\section{Materials And Methods}

\section{Samples and bacteria isolation and identification}

From March 2019 to November 2019, a total of 36 S. aureus strains were isolated from 300 raw chicken meat samples collected from Isfahan, Iran. Isolation of S. aureus was performed according to method described by F Safarpoor Dehkordi, H Gandomi, A Akhondzadeh Basti, A Misaghi and E Rahimi [6]. Briefly, $25 \mathrm{~g}$ of each collected samples were blended with $225 \mathrm{~mL}$ of buffered peptone water (Merck, Germany). At that moment, solutions were homogenized using Stomacher (Interscience, Saint-Nom, France). At that time, five milliliters of the achieved solution was transferred into $50 \mathrm{~mL}$ Trypticase Soy Broth (TSB, Merck, Germany) supplemented with $10 \% \mathrm{NaCl}$ and $1 \%$ sodium pyruvate and incubated for $18 \mathrm{~h}$ at $35^{\circ} \mathrm{C}$. At that moment, a loopful of the culture was transferred into Baird-Parker agar supplemented with egg yolk tellurite emulsion (Merck, Germany) and incubated at $37^{\circ} \mathrm{C}$ for about $24 \mathrm{~h}$. Black shiny colonies enclosed with significant zones were identified using biochemical tests including Gram staining, oxidase test, catalase activity, resistance to bacitracin $(0.04 \mathrm{U})$, coagulated test (rabbit plasma), urease activity, glucose O/F test, voges-proskaver (Merck, Germany) test, nitrate reduction, phosphatase, deoxyribonuclease (DNase, Merck, Germany) test, mannitol fermentation, hemolysis activity on blood agar (Merck, Germany) and carbohydrate (xylose, sucrose, trehalose and maltose, fructose, lactose, mannose) fermentation tests [6].

\section{Phenotypic evaluation of antibiotic resistance}

Patterns of antibiotic resistance of the $S$. aureus bacteria was assessed using the simple disk diffusion according to the Kirby-Baur technique. The Mueller-Hinton agar (Merck, Germany) was used for this goal. Susceptibility of $S$. aureus isolates were examined toward 11 diverse antibiotic disks (Oxoid, UK) including penicillin (10 $\mathrm{g}$ /disk), trimethoprim/sulfamethoxazole ( $25 \mu \mathrm{g} / \mathrm{disk})$, cephalothin $(30 \mu \mathrm{g} / \mathrm{disk})$, tetracycline $(10 \mu \mathrm{g} / \mathrm{disk})$, ciprofloxacin $(10 \mu \mathrm{g} / \mathrm{disk})$, nitrofurantoin $(300 \mu \mathrm{g} / \mathrm{disk})$, azithromycin $(15 \mu \mathrm{g} / \mathrm{disk})$, rifampin $(5 \mu \mathrm{g} /$ disk $)$ and erythromycin ( $15 \mu \mathrm{g} /$ disk). clindamycin ( $10 \mu \mathrm{g} /$ disk) and mupirocin $(5 \mu \mathrm{g} /$ disk). Instructions of the Clinical and Laboratory Standards Institute [64] was used to assess the susceptibility of bacteria toward antibiotic agents. The plates containing the discs were allowed to stand for at least $30 \mathrm{~min}$ before incubated at $37^{\circ} \mathrm{C}$ for $24 \mathrm{~h}$. The diameter of the zone of inhibition produced by each antibiotic disc was measured and interpreted using the CLSI zone diameter interpretative standards [64]. Staphylococcus aureus ATCC 25923 was used as quality control organism in antimicrobial susceptibility determination.

\section{Genotypic assessment of antibiotic resistance and virulence factors}

S. aureus isolates were sub-cultured on TSB media (Merck, Germany) and further incubated for $48 \mathrm{~h}$ at $37^{\circ} \mathrm{C}$. Genomic DNA was extracted from bacterial colonies using the DNA extraction kit (Thermo Fisher Scientific, St. Leon-Rot, Germany) according to manufacturer's instruction. Purity (A260/A280) and concentration of extracted DNA were then checked (NanoDrop, Thermo Scientific, Waltham, MA, USA). The truth of the DNA was assessed on a $2 \%$ agarose gel stained with ethidium bromide $(0.5 \mu \mathrm{g} / \mathrm{mL})$ (Thermo Fisher Scientific, St. Leon-Rot, Germany). Table 1 represents the list of primers and PCR conditions used for amplification of antibiotic resistance genes and virulence factors in the $S$. aureus bacteria isolated from raw chicken meat $[5,8,65,66]$. A programmable DNA thermo-cycler (Eppendorf Mastercycler 5330, EppendorfNethel-Hinz GmbH, Hamburg, Germany) was used in all PCR reactions. Amplified samples were analyzed by electrophoresis (120 V/208 mA) in $2.5 \%$ agarose gel. The gel was stained with $0.1 \%$ ethidium bromide $(0.4 \mu \mathrm{g} / \mathrm{ml})$. The UVI doc gel documentation systems (Grade GB004, Jencons PLC, London, UK) was applied for analysis of images.

Page $11 / 18$ 
Table 1

Target genes and PCR circumstances used for detection of antibiotic resistance genes and virulence factors in the $S$. aureus bacteria isolated from raw chicken meat $(5,12,67,68)$.

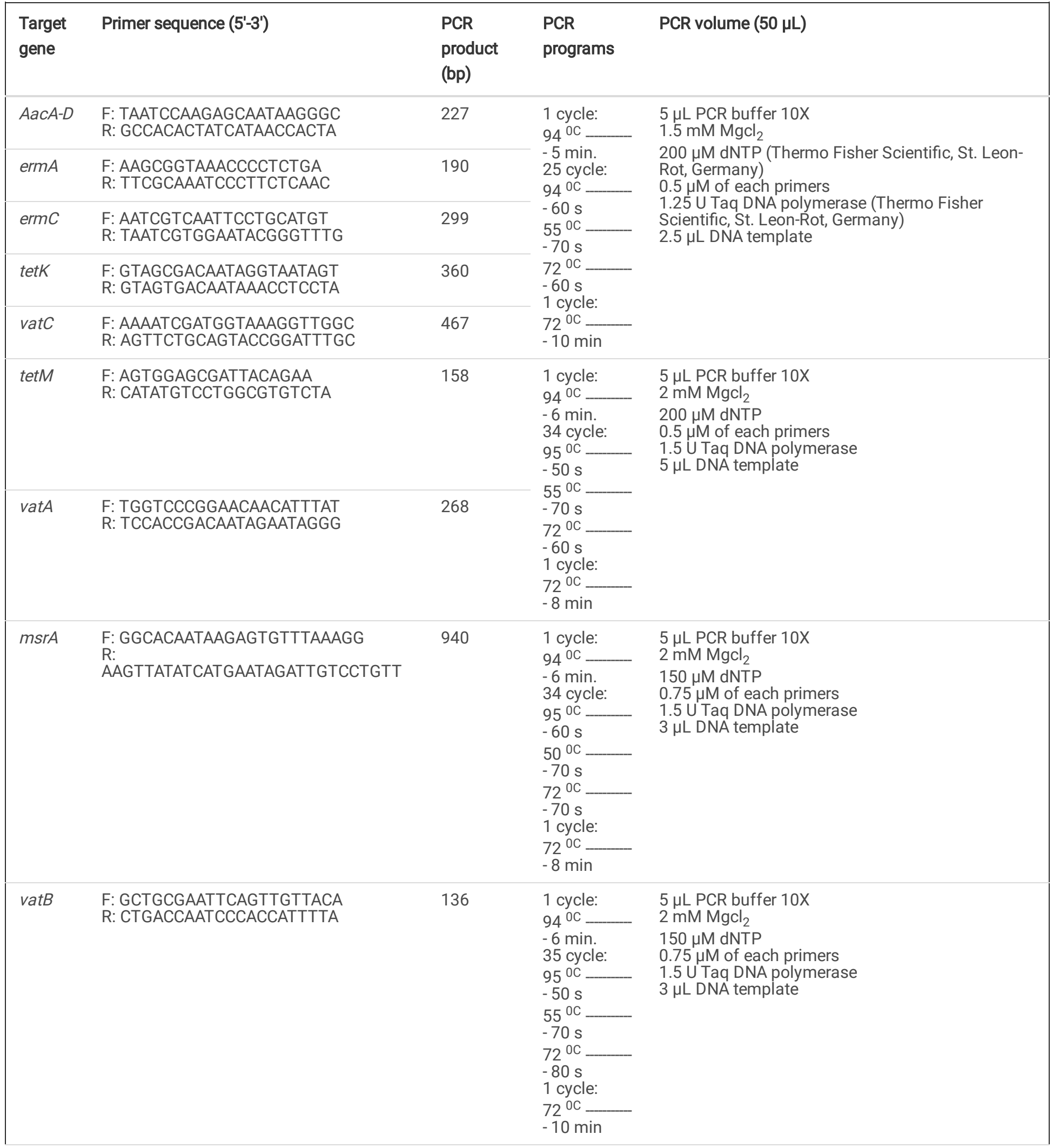




\begin{tabular}{|c|c|c|c|c|}
\hline $\begin{array}{l}\text { Target } \\
\text { gene }\end{array}$ & Primer sequence $\left(5^{\prime}-3^{\prime}\right)$ & $\begin{array}{l}\text { PCR } \\
\text { product } \\
\text { (bp) }\end{array}$ & $\begin{array}{l}\text { PCR } \\
\text { programs }\end{array}$ & PCR volume $(50 \mu \mathrm{L})$ \\
\hline $\operatorname{lin} A$ & $\begin{array}{l}\text { F: } \\
\text { GGTGGCTGGGGGGTAGATGTATTAACTGG } \\
\text { R: } \\
\text { GCTTCTTTTGAAATACATGGTATTTTTCGA }\end{array}$ & 323 & $\begin{array}{l}1 \text { cycle: } \\
94^{\circ \mathrm{C}} \\
-6 \text { min. } \\
30 \text { cycle: } \\
95^{0 \mathrm{C}} \\
-60 \mathrm{~s} \\
57^{0 \mathrm{C}} \\
-60 \mathrm{~s} \\
72^{0 \mathrm{C}} \\
-60 \mathrm{~s} \\
1 \mathrm{cycle}: \\
72^{0 \mathrm{C}} \\
-10 \mathrm{~min}\end{array}$ & $\begin{array}{l}5 \mu \mathrm{L} \text { PCR buffer } 10 \mathrm{X} \\
2 \mathrm{mM} \mathrm{Mgcl} \\
150 \mu \mathrm{M} \mathrm{dNTP} \\
0.75 \mu \mathrm{M} \text { of each primers } \\
1.5 \text { U Taq DNA polymerase } \\
3 \mu \mathrm{L} \text { DNA template }\end{array}$ \\
\hline mecA & $\begin{array}{l}\text { F: ACGAGTAGATGCTCAATATAA } \\
\text { R: CTTAGTTCTTTAGCGATTGC }\end{array}$ & 293 & $\begin{array}{l}1 \text { cycle: } \\
94 \text { OC } \\
-3 \text { min. } \\
30 \text { cycle: } \\
94 \text { OC } \\
-30 \mathrm{~s} \\
60 \text { OC } \\
-30 \mathrm{~s} \\
72^{0 \mathrm{C}} \\
-30 \mathrm{~s} \\
1 \mathrm{cycle}: \\
72^{0 \mathrm{C}} \\
-10 \mathrm{~min}\end{array}$ & $\begin{array}{l}5 \mu \mathrm{L} \mathrm{PCR} \mathrm{buffer} 10 \mathrm{X} \\
2 \mathrm{mM} \mathrm{MgCl}_{2} \\
150 \mu \mathrm{M} \mathrm{dNTP} \\
0.75 \mu \mathrm{M} \text { of each primers } \\
1.5 \text { U Taq DNA polymerase } \\
3 \mu \mathrm{L} \text { DNA template }\end{array}$ \\
\hline$m s r B$ & $\begin{array}{l}\text { F: TATGATATCCATAATAATTATCCAATC } \\
\text { R: } \\
\text { AAGTTATATCATGAATAGATTGTCCTGTT }\end{array}$ & 595 & $\begin{array}{l}1 \text { cycle: } \\
940 \mathrm{CC} \\
-2 \text { min. } \\
25 \text { cycle: } \\
94^{0 \mathrm{C}} \\
-60 \mathrm{~s} \\
50 \text { OC } \\
-60 \mathrm{~s} \\
72^{0 \mathrm{C}} \\
-90 \mathrm{~s} \\
1 \mathrm{cycle}: \\
72^{0 \mathrm{C}} \\
-8 \mathrm{~min}\end{array}$ & $\begin{array}{l}5 \mu \mathrm{L} \text { PCR buffer } 10 \mathrm{X} \\
2 \mathrm{mM} \mathrm{Mgcl} \\
150 \mu \mathrm{M} \mathrm{dNTP} \\
0.75 \mu \mathrm{M} \text { of each primers } \\
1.5 \text { U Taq DNA polymerase } \\
3 \mu \mathrm{L} \text { DNA template }\end{array}$ \\
\hline clfA & $\begin{array}{l}\text { F: GGCTTCAGTGCTTGTAGG } \\
\text { R: TTTTCAGGGTCAATATAAGC }\end{array}$ & 980 & $\begin{array}{l}1 \text { cycle: } \\
94 \text { OC } \\
-4 \text { min. } \\
35 \text { cycle: } \\
94^{\circ \mathrm{C}} \\
-1 \mathrm{~min} \\
57 \text { OC } \\
-1 \mathrm{~min} \\
72^{\text {OC }} \\
-1 \mathrm{~min} \\
1 \text { cycle: } \\
72^{0 \mathrm{C}} \\
-5 \mathrm{~min}\end{array}$ & $\begin{array}{l}5 \mu \mathrm{L} \text { PCR buffer } 10 \mathrm{X} \\
2 \mathrm{mM} \mathrm{Mgcl} \\
200 \mu \mathrm{M} \text { dNTP (Fermentas) } \\
0.5 \mu \mathrm{M} \text { of each primers } \mathrm{F} \& \mathrm{R} \\
1.5 \mathrm{U} \text { Taq DNA polymerase (Fermentas) } \\
5 \mu \mathrm{L} \text { DNA template }\end{array}$ \\
\hline
\end{tabular}




\begin{tabular}{|c|c|c|c|c|}
\hline $\begin{array}{l}\text { Target } \\
\text { gene }\end{array}$ & Primer sequence $\left(5^{\prime}-3^{\prime}\right)$ & $\begin{array}{l}\text { PCR } \\
\text { product } \\
\text { (bp) }\end{array}$ & $\begin{array}{l}\text { PCR } \\
\text { programs }\end{array}$ & PCR volume $(50 \mu \mathrm{L})$ \\
\hline coa & $\begin{array}{l}\text { F: CGAGACCAAGATTCAACAAG } \\
\text { R: AAAGAAAACCACTCACATCA }\end{array}$ & 970 & $\begin{array}{l}1 \text { cycle: } \\
95^{0 \mathrm{C}} \\
-2 \mathrm{~min} . \\
30 \text { cycle: } \\
95^{\circ \mathrm{C}} \\
-30 \mathrm{~s} \\
58 \text { oc } \\
-2 \mathrm{~min} \\
72^{\circ \mathrm{C}} \\
-4 \mathrm{~min} \\
1 \text { cycle: } \\
72^{0 \mathrm{C}} \\
-7 \mathrm{~min}\end{array}$ & 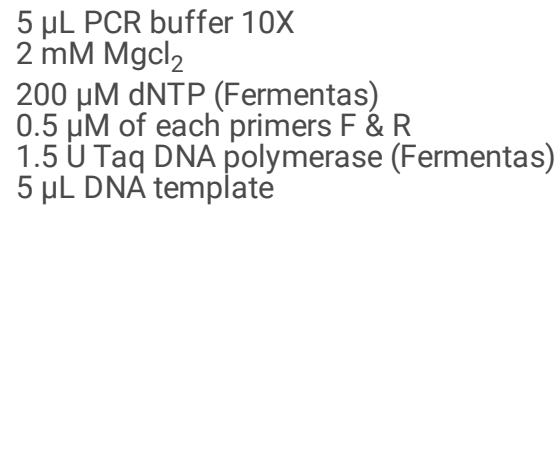 \\
\hline tsst-1 & $\begin{array}{l}\text { F: ATGGCAGCATCAGCTTGATA } \\
\text { R: TTTCCAATAACCACCCGTTT }\end{array}$ & 350 & \multirow{3}{*}{$\begin{array}{l}1 \text { cycle: } \\
94 \text { oc } \\
-6 \text { min. } \\
30 \text { cycle: } \\
94 \text { oc } \\
-2 \text { min } \\
55 \text { oc } \\
-2 \text { min } \\
72 \text { oc } \\
-1 \text { min } \\
1 \text { cycle: } \\
72 \text { oc } \\
-8 \text { min }\end{array}$} & \multirow{3}{*}{ 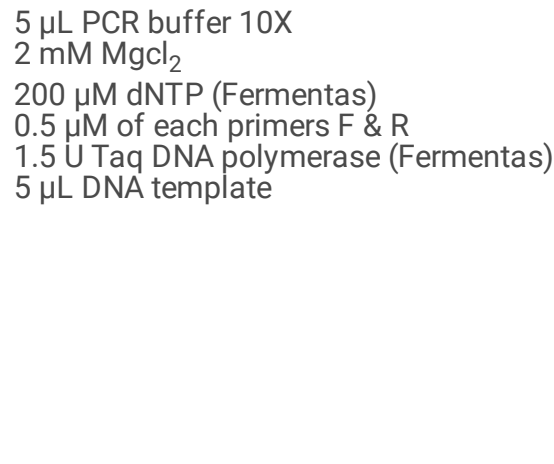 } \\
\hline et $A$ & $\begin{array}{l}\text { F: CTAGTGCATTTGTTATTCAA } \\
\text { R: TGCATTGACACCATAGTACT }\end{array}$ & 119 & & \\
\hline etB & $\begin{array}{l}\text { F: ACGGCTATATACATTCAATT } \\
\text { R: TCCATCGATAATATACCTAA }\end{array}$ & 200 & & \\
\hline
\end{tabular}

\section{Molecular typing}

DNA samples were amplified by PCR for the repetitive element sequence using the primer ERIC-PCR: ERIC1R: 5'-

ATGTAAGCTCCTGGGGATTCAC-3', ERIC2: 5'-AAGTAAGTGACTGGGGTGAGC-3'[67, 68]. Electrophoretic patterns were analyzed either visually or by using the Bionumerics software (Applied Maths, Sint-Martems-Latem, Belgium). The BioNumerics analysis was performed using the Dice coefficient and the unweighted pair group method of averages (UPGMA) with a $1 \%$ tolerance limit and $1 \%$ optimization. Isolates that clustered with $\geq 80 \%$ similarity were considered to belong to the same ERIC type, respectively.

\section{Statistical analysis}

Statistical analysis was done using the SPSS 21.0 statistical software (SPSS Inc., Chicago, IL, USA). Chi-square test and Fisher's exact twotailed test were used to assess any significant relationship between the phenotypic and genotypic properties of antibiotic resistance, virulence factors and molecular typing of $S$. aureus bacteria. $P$ value $<0.05$ was considered as statistical significant level.

\section{Declarations}

\section{Ethics approval and consent to participate}

The research was extracted from the Ph.D thesis in the field of Microbiology and was ethically approved by the Council of Research of the Faculty of Basic Science, Shahrekord Branch, Islamic Azad University, Shahrekord, Iran (Consent Ref Number IR.IAU.SHK.REC.1398.051). Verification of this research project and the licenses related to sampling process were approved by the Prof. Hassan Momtaz (Approval Ref Number MIC201946).

\section{Consent for publication}

Not applicable.

\section{Availability of data and materials}

All data analyzed during this study are included in this published article.

\section{Competing interests}


The authors declare that they have no competing interests.

\section{Funding}

Hassan Momtaz received Research grants for Research at Islamic Azad University, Shahrekord Branch, Shahrekord, Iran (grant number 97/1106). The present work was also financially supported by the Islamic Azad University, Shahrekord Branch, Shahrekord, Iran (grant number 97/1106). Funding was specified to designation of the study, samples collection, analysis, data interpretation and writing of the manuscript.

\section{Authors' contributions}

$\mathrm{HM}$, and SK carried out the molecular genetic studies, participated in the primers sequence alignment and drafted the manuscript. NF and SK carried out the sampling and culture method. HM and NF participated in the design of the study, performed the statistical analysis and writing the manuscript. All authors read and approved the final manuscript.

\section{Acknowledgements}

The authors would like to thank Dr. Mohammad Zavarshani for his assistance in sample collection. This work was financially supported by the Islamic Azad University, Shahrekord Branch, Shahrekord, Iran.

\section{Authors' information}

${ }^{1}$ Graduated of Veterinary Medicine, Faculty of Veterinary Medicine, Shahrekord Branch, Islamic Azad University, Shahrekord, Iran, Email: fazel_dvm93@yahoo.com; ${ }^{2}$ Department of Microbiology, Shahrekord Branch, Islamic Azad University, Shahrekord, Iran, Email: hamomtaz@yahoo.com, hamomtaz@iaushk.ac.ir; karimisepideh96@gmail.com

\section{References}

1. Hemmatinezhad B, Khamesipour F, Mohammadi M, Safarpoor Dehkordi F, Mashak Z. Microbiological Investigation of O-Serogroups, Virulence Factors and Antimicrobial Resistance Properties of Shiga Toxin-Producing E scherichia Coli Isolated from Ostrich, Turkey and Quail Meats. J Food Safe. 2015;35(4):491-500.

2. Momtaz H, Davood Rahimian M, Safarpoor Dehkordi F. Identification and characterization of Yersinia enterocolitica isolated from raw chicken meat based on molecular and biological techniques. J App Poultry Res. 2013;22(1):137-45.

3. Rahimi E, Yazdanpour S, Dehkordi F. Detection of Toxoplasma gondii antibodies in various poultry meat samples using enzyme linked immuno sorbent assay and its confirmation by polymerase chain reaction. J Pure Appl Microbiol. 2014;8(1):421-7.

4. Mashak Z, Jafariaskari S, Alavi I, Shahreza MS, Dehkordi FS. Phenotypic and Genotypic Assessment of Antibiotic Resistance and Genotyping of vacA, cagA, iceA, oipA, cagE, and babA2 Alleles of Helicobacter pylori Bacteria Isolated from Raw Meat. Infect Drug Resist. 2020;13:257.

5. Abdolmaleki Z, Mashak Z, Dehkordi FS. Phenotypic and genotypic characterization of antibiotic resistance in the methicillin-resistant Staphylococcus aureus strains isolated from hospital cockroaches. Antimicrob Resist Infect Control. 2019;8(1):54.

6. Safarpoor Dehkordi F, Gandomi H, Akhondzadeh Basti A, Misaghi A, Rahimi E. Phenotypic and genotypic characterization of antibiotic resistance of methicillin-resistant Staphylococcus aureus isolated from hospital food. Antimicrob Resist Infect Control. 2017;6(1):104.

7. Hasanpour Dehkordi A, Khaji L, Sakhaei Shahreza M, Mashak Z, Safarpoor Dehkordi F, Safaee Y, et al. One-year prevalence of antimicrobial susceptibility pattern of methicillin-resistant Staphylococcus aureus recovered from raw meat. Tropical Biomed. 2017;34(2):396-404.

8. Momtaz H, Dehkordi FS, Rahimi E, Asgarifar A, Momeni M. Virulence genes and antimicrobial resistance profiles of Staphylococcus aureus isolated from chicken meat in Isfahan province, Iran. J App Poultry Res. 2013;22(4):913-21.

9. Hasanpour Dehkordi A, Khaji L, Sakhaei Shahreza M, Mashak Z, Safarpoor Dehkordi F, Safaee Y, et al. One-year prevalence of antimicrobial susceptibility pattern of methicillin-resistant Staphylococcus aureus recovered from raw meat. Trop Biomed. 2017;34(2):396-404.

10. Rahi A, Kazemeini H, Jafariaskari S, Seif A, Hosseini S, Dehkordi FS. Genotypic and Phenotypic-Based Assessment of Antibiotic Resistance and Profile of Staphylococcal Cassette Chromosome mec in the Methicillin-Resistant Staphylococcus aureus Recovered from Raw Milk. Infect Drug Resist. 2020;13:273.

11. Chaalal W, Chaalal N, Bourafa N, Kihal M, Diene SM, Rolain J-M. Characterization of Staphylococcus aureus isolated from food products in Western Algeria. Foodborne Pathogen Dis. 2018;15(6):353-60. 
12. Puah SM, Chua KH, Tan JAMA. Virulence factors and antibiotic susceptibility of Staphylococcus aureus isolates in ready-to-eat foods: detection of S. aureus contamination and a high prevalence of virulence genes. Int J Env Res Public Health. 2016;13(2):199.

13. Codjoe FS, Brown CA, Smith TJ, Miller K, Donkor ES. Genetic relatedness in carbapenem-resistant isolates from clinical specimens in Ghana using ERIC-PCR technique. PLoS One. 2019;14(9).

14. Ranjbar R, Yadollahi Farsani F, Safarpoor Dehkordi F. Antimicrobial resistance and genotyping of vacA, cagA, and iceA alleles of the Helicobacter pylori strains isolated from traditional dairy products. J Food Safe. 2019;39(2):e12594.

15. Ranjbar R, Farsani FY, Dehkordi FS. Phenotypic analysis of antibiotic resistance and genotypic study of the vacA, cagA, iceA, oipA and babA genotypes of the Helicobacter pylori strains isolated from raw milk. Antimicrob Resist Infect Control. 2018;7(1):115.

16. Ranjbar R, Dehkordi FS, Shahreza MHS, Rahimi E. Prevalence, identification of virulence factors, O-serogroups and antibiotic resistance properties of Shiga-toxin producing Escherichia coli strains isolated from raw milk and traditional dairy products. Antimicrob Resist Infect Control. 2018;7(1):53.

17. Ranjbar R, Masoudimanesh M, Dehkordi FS, Jonaidi-Jafari N, Rahimi E. Shiga (Vero)-toxin producing Escherichia coli isolated from the hospital foods; virulence factors, o-serogroups and antimicrobial resistance properties. Antimicrob Resist Infect Control. 2017;6(1):4.

18. Hiroi M, Kawamori F, Harada T, Sano Y, Miwa N, Sugiyama K, et al. Antibiotic resistance in bacterial pathogens from retail raw meats and food-producing animals in Japan. J Food Protect. 2012;75(10):1774-82.

19. Wu S, Huang J, Wu Q, Zhang J, Zhang F, Yang X, et al. Staphylococcus aureus isolated from retail meat and meat products in China: incidence, antibiotic resistance and genetic diversity. Front Microbiol. 2018;9:2767.

20. Ali Y, Islam MA, Muzahid NH, Sikder MOF, Hossain MA, Marzan LW. Characterization, prevalence and antibiogram study of Staphylococcus aureus in poultry. Asian Pacific Journal of Tropical Biomedicine. 2017;7(3):253-6.

21. Bantawa K, Sah SN, Limbu DS, Subba P, Ghimire A. Antibiotic resistance patterns of Staphylococcus aureus, Escherichia coli, Salmonella, Shigella and Vibrio isolated from chicken, pork, buffalo and goat meat in eastern Nepal. BMC Res Notes. 2019;12(1):1-6.

22. Akbar A, Anal AK. Prevalence and antibiogram study of Salmonella and Staphylococcus aureus in poultry meat. Asian Pacific J Tropic Biomed. 2013;3(2):163-8.

23. Haskell KJ, Schriever SR, Fonoimoana KD, Haws B, Hair BB, Wienclaw TM, et al. Antibiotic resistance is lower in Staphylococcus aureus isolated from antibiotic-free raw meat as compared to conventional raw meat. PloS one. 2018;13(12).

24. Rahimi F, Karimi S. Characteristics of methicillin resistant staphylococcus aureus strains isolated from poultry in iran. Arch Clin Infect Dis. $2015 ; 10(4)$.

25. Govender V, Madoroba E, Magwedere K, Fosgate G, Kuonza L. Prevalence and risk factors contributing to antibiotic-resistant Staphylococcus aureus isolates from poultry meat products in South Africa, 2015-2016. J South African Vet Associat. 2019;90(1):1-8.

26. Amoako DG, Somboro AM, Abia AL, Molechan C, Perrett K, Bester LA, et al. Antibiotic Resistance in Staphylococcus aureus from Poultry and Poultry Products in uMgungundlovu District, South Africa, Using the "Farm to Fork" Approach. Microb Drug Resist. 2019.

27. Wendlandt S, Schwarz S, Silley P. Methicillin-resistant Staphylococcus aureus: a food-borne pathogen? Annual Rev Food Sci Techno. 2013:4:117-39.

28. Riva A, Borghi E, Cirasola D, Colmegna S, Borgo F, Amato E, et al. Methicillin-resistant Staphylococcus aureus in raw milk: Prevalence, SCC mec typing, enterotoxin characterization, and antimicrobial resistance patterns. J Food Protect. 2015;78(6):1142-6.

29. Paludi D, Vergara A, Festino AR, Di Ciccio P, Costanzo C, Conter M, et al. Antimicrobial resistance pattern of methicillin-resistant Staphylococcus aureus in the food industry. J Bio Regulat Homeost Agent. 2011;25(4):671.

30. Sallam KI, Abd-Elghany SM, Elhadidy M, Tamura T. Molecular characterization and antimicrobial resistance profile of methicillin-resistant Staphylococcus aureus in retail chicken. J Food Protect. 2015;78(10):1879-84.

31. Jackson CR, Davis JA, Barrett JB. Prevalence and characterization of methicillin-resistant Staphylococcus aureus isolates from retail meat and humans in Georgia. J Clin Microbiol. 2013;51(4):1199-207.

32. Daka D, Yihdego D. Antibiotic-resistance Staphylococcus aureus isolated from cow's milk in the Hawassa area, South Ethiopia. Ann Clin Microbiol Antimicrob. 2012;11(1):26.

33. Akanbi OE, Njom HA, Fri J, Otigbu AC, Clarke AM. Antimicrobial susceptibility of Staphylococcus aureus isolated from recreational waters and beach sand in Eastern Cape Province of South Africa. Int J Env Res Public Health. 2017;14(9):1001.

34. Osman K, Badr J, Al-Maary KS, Moussa IM, Hessain AM, Girah Z, et al. Prevalence of the antibiotic resistance genes in coagulase-positiveand negative-Staphylococcus in chicken meat retailed to consumers. Front Microbiol. 2016;7:1846.

35. Johler S, Layer F, Stephan R. Comparison of virulence and antibiotic resistance genes of food poisoning outbreak isolates of Staphylococcus aureus with isolates obtained from bovine mastitis milk and pig carcasses. J Food Protect. 2011;74(11):1852-9. 
36. Strommenger B, Kettlitz C, Werner G, Witte W. Multiplex PCR assay for simultaneous detection of nine clinically relevant antibiotic resistance genes in Staphylococcus aureus. J Clin Microbiol. 2003;41(9):4089-94.

37. Rahimi H, Saei HD, Ahmadi M. Nasal carriage of Staphylococcus aureus: Frequency and antibiotic resistance in healthy ruminants. Jundishapur J Microbiol. 2015;8(10).

38. Merz A, Stephan R, Johler S. Staphylococcus aureus isolates from goat and sheep milk seem to be closely related and differ from isolates detected from bovine milk. Front Microbiol. 2016;7:319.

39. Jamali H, Paydar M, Radmehr B, Ismail S, Dadrasnia A. Prevalence and antimicrobial resistance of Staphylococcus aureus isolated from raw milk and dairy products. Food Control. 2015;54:383-8.

40. Hizlisoy H, Onmaz NE, Karadal F, Serhat A, Yildirim Y, Gonulalan Z, et al. Antibiotic Resistance Gene Profiles of Staphylococcus aureus Isolated From Foods of Animal Origin. Kafkas Üni Vet Fakült Derg. 2018;24(2).

41. Groves MD, Crouch B, Coombs GW, Jordan D, Pang S, Barton MD, et al. Molecular epidemiology of methicillin-resistant Staphylococcus aureus isolated from Australian veterinarians. PLoS One. 2016;11(1).

42. Gomes RM, Bomfim MRQ, Trindade MJ, Farias LM, Santos SG. Potential Spread of Methicillin-Resistant Staphylococcus aureus Recovered from Patients with Bloodstream Infection. Chemo Open Access. 2015;4(2):1000149.

43. Adwan G, Adwan K, Jarrar N, Amleh A. Molecular detection of nine antibiotic resistance genes in methicillin resistant Staphylococcus aureus isolates. Romanian Arch Microbiol Immunol. 2014;73(1-2):9-18.

44. Oksuz L, Dupieux C, Tristan A, Bes M, Etienne J, Gurler N. The high diversity of MRSA clones detected in a university hospital in Istanbul. Int J Medical Sci. 2013;10(12):1740.

45. Zmantar T, Chaieb K, Abdallah FB, Kahla-Nakbi AB, Hassen AB, Mahdouani K, et al. Multiplex PCR detection of the antibiotic resistance genes in Staphylococcus aureus strains isolated from auricular infections. Folia Microbiol. 2008;53(4):357.

46. Dehkordi SF, Basti A, Gandomi H, Misaghi A, Rahimi E. Pathogenic Staphylococcus aureus in hospital food samples; prevalence and antimicrobial resistance properties (Retraction of Vol 38, art no E12501, 2018). in.: wiley 111 river st, hoboken 07030 - 5774 , nj usa; 2019.

47. Martineau F, Picard FJ, Lansac N, Ménard C, Roy PH, Ouellette M, et al. Correlation between the Resistance Genotype Determined by Multiplex PCR Assays and the Antibiotic Susceptibility Patterns of Staphylococcus aureus and Staphylococcus epidermidis. Antimicrob Agent Chem. 2000;44(2):231-8.

48. Moon J-S, Lee A-R, Kang H-M, Lee E-S, Kim M-N, Paik Y, et al. Phenotypic and genetic antibiogram of methicillin-resistant staphylococci isolated from bovine mastitis in Korea. J Dairy Sci. 2007;90(3):1176-85.

49. Pehlivanoğlu F, Yardımcı H. Detection of methicillin and vancomycin resistance in Staphylococcus strains isolated from bovine milk samples with mastitis. 2012.

50. Ranjbar R, Shahreza MHS, Rahimi E, Jonaidi-Jafari N. Methicillin-resistant Staphylococcus aureus isolates from Iranian restaurant food samples: Panton-Valentine Leukocidin, SCCmec phenotypes and antimicrobial resistance. Tropical J Pharma Res. 2017;16(8):1939-49.

51. Abdolmaleki Z, Mashak Z, Safarpoor Dehkordi F. Molecular and Virulence Characteristics of Methicillin-Resistant Staphylococcus aureus Bacteria Recovered From Hospital Cockroaches. Jundishapur J Microbiol. 2019;12(12).

52. Momtaz H, Rahimi E, Tajbakhsh E. Detection of some virulence factors in Staphylococcus aureus isolated from clinical and subclinical bovine mastitis in Iran. African J Biotech. 2010;9(25):3753-8.

53. Coelho SM, Reinoso E, Pereira IA, Soares LC, Demo M, Bogni C, et al. Virulence factors and antimicrobial resistance of Staphylococcus aureus isolated from bovine mastitis in Rio de Janeiro. Pesquisa Vet Brasil. 2009;29(5):369-74.

54. Heidari M, Momtaz H, Madani M. Detection of the antibiotic resistance genes in Staphylococcus aureus isolated from human infections and bovine mastitis. Afr J Microbiol Res. 2011;5(31):5745-9.

55. Koosha RZ, Fooladi AAI, Hosseini HM, Aghdam EM. Prevalence of exfoliative toxin A and B genes in Staphylococcus aureus isolated from clinical specimens. J Infect Public Health. 2014;7(3):177-85.

56. Li H, Andersen P, Stegger M, Sieber R, ngmer H, Staubrand N, et al. Antimicrobial Resistance and Virulence Gene Profiles of MethicillinResistant and -Susceptible Staphylococcus aureus From Food Products in Denmark. Front Microbiol. 2019;10:2681.

57. Yang X, Yu S, Wu Q, Zhang J, Wu S, Rong D. Multilocus sequence typing and virulence-associated gene profile analysis of Staphylococcus aureus isolates from retail ready-to-eat food in China. Front Microbiol. 2018;9:197.

58. Waryah CB, Gogoi-Tiwari J, Wells K, Eto KY, Masoumi E, Costantino P, et al. Diversity of virulence factors associated with West Australian methicillin-sensitive Staphylococcus aureus isolates of human origin. BioMed Res Int. 2016;2016.

59. Karahan M, Acik MN, Cetinkaya B. Investigation of virulence genes by PCR in Stapylococcus aureus isolates originated from subclinical bovine mastitis in Turkey. Pak Vet J. 2011;31(3):249-53.

Page $17 / 18$ 
60. Shopsin B, Gomez M, Waddington M, Riehman M, Kreiswirth B. Use of coagulase gene (coa) repeat region nucleotide sequences for typing of methicillin-resistant Staphylococcus aureus strains. J Clinl Microbiol. 2000;38(9):3453-6.

61. Sukhumungoon P, Bunnueang N, Butsabong N, Sae-lim A, Rattanachuay P. Characterization of staphylococcus spp from meat and readyto-eat food, hat yai city, songkhla, thailand. Southeast Asian J Tropic Med Public Health. 2018;49(1):96-107.

62. Stutz K, Stephan R, Tasara T. SpA, ClfA, and FnbA genetic variations lead to Staphaurex test-negative phenotypes in bovine mastitis Staphylococcus aureus isolates. J Clin Microbiol. 2011;49(2):638-46.

63. Yadav R, Sharma SK, Yadav J, Kataria AK. Typing of Staphylococcus aureus obtained from mastitic milk of cattle and buffalo on the basis of two virulence-associated genes (spa and clfA). Veterinary world. 2015;8(3):398.

64. CLSI. Performance Standards for Antimicrobial Susceptibility Testing; Twenty-Fifth Informational Supplement. In.: Wayne: Clinical and Laboratory Standards Institute; 2015: pp. M100-S25.

65. Lina G, Quaglia A, Reverdy M-E, Leclercq R, Vandenesch F, Etienne J. Distribution of genes encoding resistance to macrolides, lincosamides, and streptogramins among staphylococci. Antimicrob Agent Chem. 1999;43(5):1062-6.

66. Kumar R, Yadav B, Singh R. Genetic determinants of antibiotic resistance in Staphylococcus aureus isolates from milk of mastitic crossbred cattle. Current Microbiol. 2010;60(5):379-86.

67. Louws FJ, Fulbright DW, Stephens CT, De Bruijn F. Specific genomic fingerprints of phytopathogenic Xanthomonas and Pseudomonas pathovars and strains generated with repetitive sequences and PCR. Appl Environ Microbiol. 1994;60(7):2286-95.

68. Versalovic J, Schneider M, de Bruijn FJ, Lupski JR. Genomic fingerprinting of bacteria using repetitive sequence based PCR (rep-PCR). Meth Mol Cell Biol. 1994;5:25-40.

\section{Figures}

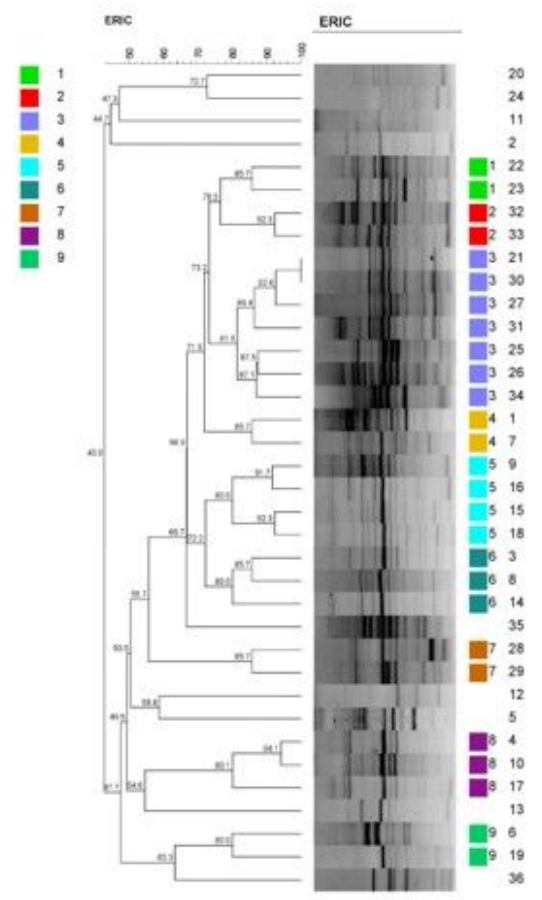

Figure 1

ERIC-based molecular typing of S. aureus strains isolated from chicken meat samples. 